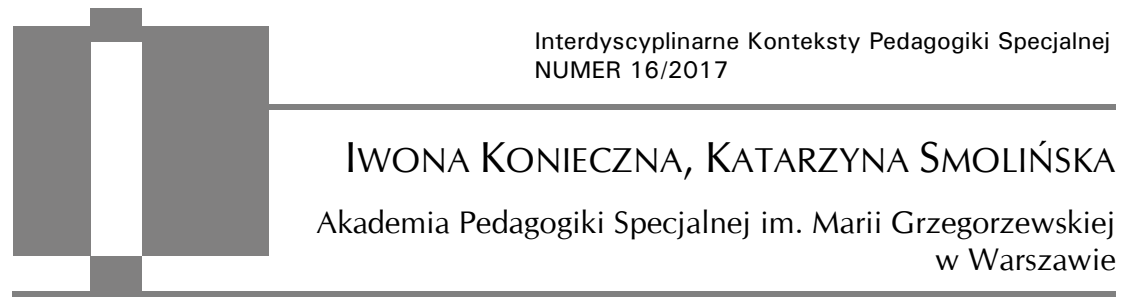

\title{
Skuteczne wspieranie Innego - rozważania nad uwarunkowaniami rozwoju zespołów terapeutycznych
}

\begin{abstract}
Iwona Konieczna, Katarzyna Smolińska, Skuteczne wspieranie Innego rozważania nad uwarunkowaniami rozwoju zespotów terapeutycznych [Effective supporting of "different” - consideration on developmental determinants therapeutic teams]. Interdyscyplinarne Konteksty Pedagogiki Specjalnej, nr 16, Poznań 2017. Pp. 101-116. Adam Mickiewicz University Press. ISSN 2300-391X

This paper will try to present developmental determinants multi specialist therapeutic teams which support people with disability (multi and trans disciplinary models of therapeutic teams).

Developmental analysis of therapeutic teams will include formal, legal, organizational and theoretical aspects (basing on Kwiatkowski professional competences development theory).
\end{abstract}

KEY WORDS: therapeutic teams, competencies of therapeutic teams, development, stagnation, competencies regression.

\section{Wprowadzenie}

Inność bardzo często utożsamiana jest z obcością, która jest uniwersalnym wariantem stosowanym niemal od zawsze do opisu i porządkowania świata społecznego. Termin ten zawiera $\mathrm{w}$ sobie pewną dwoistość znaczeniową. Mianowicie odnosi się do podo- 
bieństwa, identyczności, pozostawania niezmiennie tym samym. Mówiąc o inności, należy wspomnieć o jej dwóch podstawowych wymiarach: indywidualnym i społecznym. W pierwszym przypadku inność wskazuje na „bycie kimś” w sposób trwały i odrębny; „osadzonym” w miejscu i czasie. Natomiast drugie znaczenie odsyła do społecznych identyfikacji, utożsamiania się z kimś lub czymś.

Określenie Inny można rozumieć na wiele sposobów i używać w różnych kontekstach znaczeniach, np. dla rozróżnienia płci, pokoleń, narodowości, religii ${ }^{1}$, a także $\mathrm{w}$ zakresie niepełnosprawności.

W literaturze pedagogicznej bardzo często wskazywany jest niejednoznaczny charakter kategorii inności. Może ona być podstawą do wskazywania różnic między jednostkami lub grupami, które w społecznym wymiarze mogą być inaczej postrzegane. Warto zaznaczyć, iż sposób postrzegania nie zawsze ma charakter ujemnego wartościowania, wywołującego negatywne nastawienie i oceny ${ }^{2}$. Inność jako swoista różnorodność jest uznana za pewna normę i wartość w wymiarze społecznym.

Działalność na rzecz wsparcia Innego ma wieloletnią tradycję, która przejawia się w zróżnicowanych formach. W zakresie tych działań mieszczą się bezpośrednie usługi leczniczo rehabilitacyjne, różnego rodzaju świadczenia socjalne, organizacja stanowisk pracy, a także działalność kulturalna, edukacyjna i sportowa.

Zarysowane podejście do procesu rehabilitacji jest wyraźnie ulokowane na gruncie pedagogiki specjalnej, choć odwołuje się również do innych dyscyplin naukowych, tym samym niosąc ze sobą walory interdyscyplinarne. Jest zarazem próbą odpowiedzi na pytanie o istotę rozwiązań praktycznego aspektu działania pomocowego, w odniesieniu do osób o ograniczonej sprawności³.

${ }^{1}$ R. Kapuściński, Ten Inny, Wydawnictwo Znak, Kraków 2006, s. 9.

2 K.D. Rzedzicka, Nauczycielska relacja z Innym w pedagogice specjalnej, [w:] Pedagogika specjalna szansa na realizację potrzeb osób z odchyleniami od normy, red. W. Dykcik, Cz. Kosakowski, J. Kuczyńska-Kwapisz Wydawnictwo Naukowe PTP, Olsztyn - Poznań - Warszawa 2009, s. 144-145.

3 J. Sowa, Znaczenie procesu instytucji wspomagajacych proces rehabilitacji, "Szkoła Specjalna" 2003, nr 3(220) tom LXIV, s. 136-147. 
Zespół terapeutyczny stanowią osoby o odpowiednich kwalifikacjach, których podstawowym zadaniem jest współpraca poszczególnych specjalistów ze sobą tak, aby umożliwiała ona realizowanie indywidualnie zróżnicowanych terapeutycznych celów wspierania Innego. W ramach wzajemnej współpracy poszczególnych osób niezwykle ważne jest branie świadomej odpowiedzialności za podejmowane działania. Ponadto istotną kwestią jest sprawny przepływ informacji, a także dokładność i rzetelność we wzajemnym ich przekazywaniu. To pozwala na dokonywanie systematycznej oceny i ewaluacji wspólnie wyznaczonych celów terapeutycznych w kontekście wspierania poszczególnych osób i/lub grup.

Założenia dotyczące współpracy $\mathrm{w}$ ramach zespołu terapeutycznego wiążą się jeszcze z posiadaniem świadomości przez poszczególnych członków zespołu, iż także ich obowiązkiem jest wdrażanie Innego do współpracy z poszczególnymi specjalistami oraz rozwijanie $\mathrm{w}$ nim motywacji do podejmowania aktywności $\mathrm{w}$ procesie szeroko rozumianej rehabilitacji ${ }^{4}$.

Zespół terapeutyczny buduje różne relacje z Innym. Wynika to z pewnych indywidualnych cech każdej osoby. Należy pamiętać, iż każdy kontakt nawiązany $\mathrm{z}$ osobą wspieraną nie będzie miał charakteru relacji terapeutycznej. Bywa, iż pozostanie on instrumentalnie i mechaniczne nawiązanym kontaktem. Warunkiem, aby tak się nie stało jest to, że oba podmioty (specjalista - Inny) powinni aktywnie uczestniczyć we wzajemnym kontakcie i wyznaczać wspólnie kierunek powstającej relacji. Działanie to ma charakter procesu wymagającego aktywnego współuczestnictwa Innego.

\section{Formalno-prawne uwarunkowania funkcjonowania zespołów terapeutycznych}

Wspieranie osób z niepełnosprawnością jest procesem celowym, zorganizowanym, indywidualnie zróżnicowanym i systematycznie

${ }^{4}$ E. Wilczek-Rużyczka, Komunikowanie się z chorym psychicznie, Wydawnictwo Czelej, Lublin 2007, s. 35. 
realizowanym. W sensie formalnym rozpoczyna się on po przeprowadzonej diagnozie nozologicznej i stwierdzeniu niepełnosprawności, którego skutkiem jest wydanie odpowiedniego dokumentu ją potwierdzającego (np. orzeczenia o potrzebie kształcenia specjalnego, orzeczenie o potrzebie zajęć rewalidacyjno-wychowawczych orzeczenie o stanie niepełnosprawności). Posiadanie dokumentu uprawnia osobę z niepełnosprawnością do korzystania ze specjalistycznych usług. Należy podkreślić, że proces wspierania rozpoczyna się w różnych okresach i trwa przez całe życie.

Wspieranie Innego w Polsce ciągle jeszcze nie stanowi spójnego systemu, a to oznacza, że organizowane jest przez różne resorty. Konsekwencją tego są zróżnicowane uregulowania prawne dotyczące funkcjonowania zespołów terapeutycznych.

W prawie oświatowym regulacje dotyczące organizowania i funkcjonowania zespołów terapeutycznych pojawiają się m.in. w następujących dokumentach (Rozporządzenie Ministra Edukacji Narodowej $\mathrm{w}$ sprawie organizowania wczesnego wspomagania $\mathrm{z}$ dnia 11.10.2013 r. i 3.03.2009 r. (Dz. U. poz. 1257 z dnia 11.10.2013 r. i Dz. U. poz. 133 z dnia 3.02.2009 r.); Rozporządzenie Ministra Edukacji Narodowej w sprawie warunków organizowania kształcenia, wychowania i opieki dla dzieci i młodzieży niepełnosprawnych, niedostosowanych społecznie i zagrożonych niedostosowaniem społecznym z dnia 24.07.2015 r. (Dz. U. poz. 1113). Tworzenie zespołów terapeutycznych widoczne jest już na etapie wczesnego wspomagania rozwoju. Skład i zakres działań zespołu określa Rozporządzenie Ministra Edukacji Narodowej w sprawie organizowania wczesnego wspomagania ${ }^{5}$. Kluczową rolę zespołu w przygotowaniu wielospecjalistycznej oceny poziomu funkcjonowania dziecka oraz opracowaniu indywidualnego programu edukacyjno-terapeutycznego określa Rozporządzenie Ministra Edukacji Narodowej w sprawie warunków organizowania kształcenia, wychowania

${ }^{5}$ Rozporządzenie Ministra Edukacji Narodowej w sprawie organizowania wczesnego wspomagania z dnia 11.10.2013 r. i 3.03.2009 r. (Dz. U. poz. 1257 z dnia 11.10.2013 r. i Dz. U. poz. 133 z dnia 3.02.2009 r.). 
i opieki dla dzieci i młodzieży niepełnosprawnych, niedostosowanych społecznie i zagrożonych niedostosowaniem społecznym ${ }^{6}$.

$\mathrm{W}$ zakresie rehabilitacji społeczno-zawodowej istotne jest działanie zespołu terapeutycznego jako Rady Programowej (w skład której wchodzą: kierownik, terapeuci zajęciowi, specjaliści do spraw rehabilitacji i rewalidacji, psycholog), której nadrzędnym zadaniem jest opracowanie corocznych indywidualnych programów rehabilitacji dla każdego uczestnika. Zadanie te ściśle określa Rozporządzenie Ministra Gospodarki, Pracy i Polityki Społecznej z dnia 25.03.2004 r. w sprawie warsztatów terapii zajęciowej’.

Z kolei w placówkach leczniczych pracę zespołów regulują akty prawne odnoszące się do funkcjonowania szpitali, prewentoriów, poradni zdrowia psychicznego i placówek sanatoryjnych. Wśród nich można wyróżnić: Ustawę z dnia 15.04.2011 r. o działalności leczniczej;; Rozporządzenie Ministra Zdrowia z dnia 21.12.2010 r. w sprawie rodzajów i zakresu dokumentacji medycznej oraz sposobu jej przetwarzania9; Ustawę z dnia 27.08.2004 r. o świadczeniach opieki zdrowotnej finansowanych ze środków publicznych ${ }^{10}$; Rozporządzenie Ministra Zdrowia z dnia 27.12.2007 r. w sprawie sposobu i kryteriów ustalania dopuszczalnego czasu oczekiwania na wybrane świadczenia opieki zdrowotnej ${ }^{11}$; Rozporządzenie Mini-

${ }^{6}$ Rozporządzenie Ministra Edukacji Narodowej w sprawie warunków organizowania kształcenia, wychowania i opieki dla dzieci i młodzieży niepełnosprawnych, niedostosowanych społecznie i zagrożonych niedostosowaniem społecznym z dnia 24.07.2015 r. (Dz. U. poz. 1113).

${ }^{7}$ Rozporządzenie Ministra Gospodarki, Pracy i Polityki Społecznej z dnia 25.03.2004 r. w sprawie warsztatów terapii zajęciowej (Dz. U. Nr 63, poz. 586 i 587).

${ }^{8}$ Ustawa z dnia 15.04.2011 r. o działalności leczniczej (Dz.U. z 15.02.2013 r., poz. 217 j.t. z późn. zm.).

${ }^{9}$ Rozporządzenie Ministra Zdrowia z dnia 21.12.2010 r. w sprawie rodzajów i zakresu dokumentacji medycznej oraz sposobu jej przetwarzania (Dz. U. z dnia 29.12.2010 r. Nr 252, poz. 1697).

${ }^{10}$ Ustawa z dnia 27.08.2004 r. o świadczeniach opieki zdrowotnej finansowanych ze środków publicznych (Dz. U. z 11.09.2008 r., Nr 164, poz. 1027 j.t. z późn. zm.).

${ }^{11}$ Rozporządzenie Ministra Zdrowia z dnia 27.12.2007 r. w sprawie sposobu i kryteriów ustalania dopuszczalnego czasu oczekiwania na wybrane świadczenia opieki zdrowotnej (Dz. U. z 31.12.2007 r., Nr 250, poz. 1884). 
stra Zdrowia z dnia 29.08.2009 r. w sprawie świadczeń gwarantowanych z zakresu podstawowej opieki zdrowotnej ${ }^{12}$. Warto podkreślić, iż szczegółowy zakres i organizację działań podmiotów medycznych, w tym zespołów specjalistów, określają wewnętrzne procedury, a także statuty danych placówek leczniczych.

\section{Rozwój kompetencji zespołów terapeutycznych}

Pojęcie kompetencji ujmowane jest w różnorodny sposób i analizowane na wielu płaszczyznach znaczeniowych. W artykule przyjmujemy definicję, w której termin kompetencje (łac. competentia) definiuje się jako „zdolność i gotowość podmiotu do wykonania zadań na określonym poziomie; powstaje $\mathrm{w}$ wyniku zintegrowania wiedzy, dużej liczby drobnych umiejętności oraz sprawności w dokonywaniu wartościowań"13. Kompetencje określane są jako: 1) podstawa sprawności działania, 2) warunek konstruowania psychospołecznej tożsamości jednostki, 3) zdolność refleksyjnego działania, 4) warunek dystansującego rozumienia, 5) potencjał działania o charakterze emancypacyjnym ${ }^{14}$.

Ogólna definicja rozwoju kompetencji odnosi się do „długotrwałego procesu ukierunkowanych zmian, w którym można wyróżnić prawidłowo następujące po sobie etapy przemian danego obiektu, wykazujące stwierdzalne zróżnicowanie się tego obiektu pod określonym względem” lub „procesu kierunkowych przemian, w toku którego obiekty przechodzą od form lub stanów prostszych,

12 Rozporządzenie Ministra Zdrowia z dnia 29.08.2009 r. w sprawie świadczeń gwarantowanych z zakresu podstawowej opieki zdrowotnej (Dz.U. z 31.08.2009 r., Nr 139, poz. 1139).

${ }^{13}$ H. Kwiatkowska, Pedeutologia, Wydawnictwa Akademickie i Profesjonalne, Warszawa 2008, s. 35.

${ }^{14}$ H. Kwiatkowska, Pedeutologia, Wydawnictwa Akademickie i Profesjonalne, Warszawa 2008. J. Szempruch, Kompetencja komunikacyjna nauczycieli w dziataniach edukacyjnych, [w:] Edukacja jutra. Aspekty wychowania i ksztatcenia we wspótczesnej szkole, red. A. Kamińska, P. Oleśniewicz, Oficyna Wydawnicza Humanitas, Sosnowiec 2016, s. 277-289. 
mniej doskonałych, do form lub stanów bardziej złożonych doskonalszych pod określonym względem" 15 .

Uwzględniając kryterium organizacji i funkcjonowania poszczególnych zespołów terapeutycznych wspierających Innego, można wyróżnić trzy podstawowe modele zespołów: mulitidyscyplinarnym, interdyscyplianrnym, transdyscyplinarnym (schemat 1).

W mulidyscyplinarnym zespole terapeutycznym każdy ze specjalistów realizuje zadania zgodnie $\mathrm{z}$ posiadanymi kwalifikacjami. Oznacza to, że przygotowuje diagnozę (np. logopedyczną, psychologiczną), opracowuje osobny plan wspierania osoby/dziecka z niepełnosprawnością, spotyka się z rodzicami/opiekunami dziecka.

W swoich zawodowych działaniach uwzględnia on jedynie swoją specjalizację, co też determinuje branie odpowiedzialności tylko za „swój plan” działania realizowany zgodnie ze swoim obszarem zainteresowań i kompetencjami. Znamienne jest to, iż sposoby komunikowania się członków zespołu mają charakter nieformalnego przekazywania informacji. Odnosząc się do podstawowych założeń teoretycznych, w modelu multidyscyplinarnym każdy ze specjalistów przyjmuje założenia swoistej dla własnej dyscypliny oraz dokonuje niezależnego doskonalenia zawodowego w jej obrębie.

Model multidyscyplinarny jest uznawany za konstrukt najbardziej tradycyjny, występujący w poradniach służby zdrowia i w poradnictwie psychologiczno-pedagogicznym. Wśród niedoskonałości w jego obrębie wskazuje się to, iż dokonywana diagnoza funkcjonalna i zalecenia z niej wynikające mogą być zupełnie niedostosowane do faktycznych potrzeb Innego.

W interdyscyplinarnym modelu terapeutycznym każdy z jego członków również dokonuje diagnozy zgodnie z prezentowaną specjalizacją. W stosunku do poprzednio analizowanego zespołu zasadniczo różni się $\mathrm{w}$ zakresie: przygotowywania i realizacji programów oraz odpowiedzialności za ich efekty. Warto tu zaznaczyć, że poszczególni specjaliści uzgadniają między sobą plany pracy z Innym, co powoduje, że odpowiedzialność zgromadzonych informacji roz-

${ }^{15}$ Encyklopedia, PWN, Warszawa 1996, s. 616. 


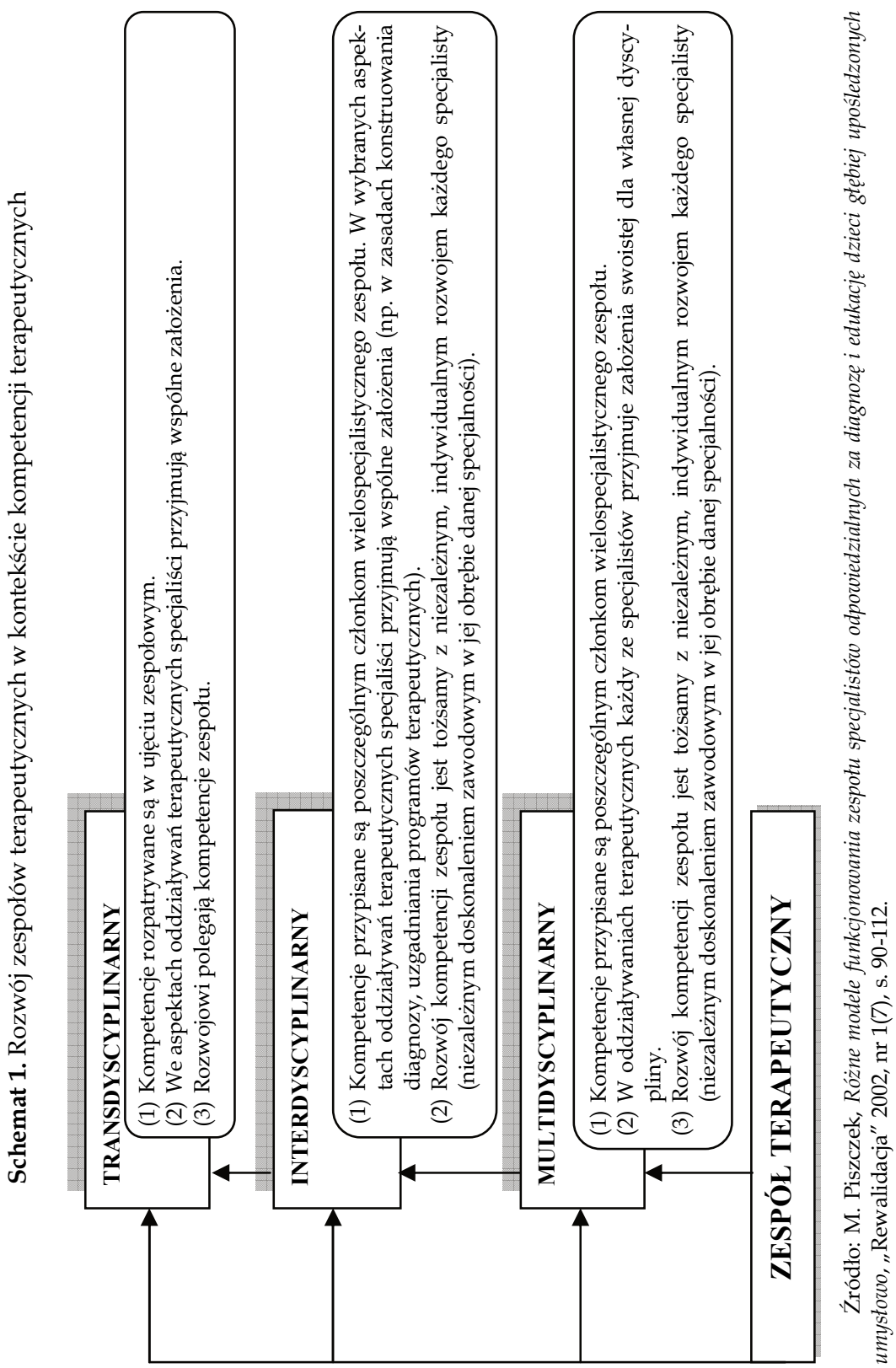


kłada się z jednej strony za propozycję własnych działań, z drugiej zaś za wspólne cele wypracowane podczas spotkań. Ma to także przełożenie na to, iż specjaliści w obrębie danego zespołu realizują nie tylko swoje części planu, ale także włączają w niego ogólnie przyjęte założenia wszystkich specjalistów, które są ustalane w trakcie niesystematycznie odbywających się spotkań, gdzie ma miejsce tzw. analiza przypadku. W prezentowanym modelu funkcjonowania zespołów rodzice spotykają się indywidualnie z każdym ze specjalistów lub przedstawicielem całego zespołu. Rozwój zespołu przebiega najczęściej w taki sposób, że poszczególni członkowie dokonują niezależnego doskonalenia zawodowego $\mathrm{w}$ stosunku do innych, wzbogacając swoje kompetencje o te, które mogą być przydatne $\mathrm{z}$ innych dyscyplin.

Maria Piszczek ${ }^{16}$ podaje, iż jest to model w obrębie którego funkcjonują placówki opiekuńczo-edukacyjne dla dzieci i młodzieży z niepełnosprawnością. Jednak zauważa się, iż specjaliści ujawniają wiele uwag i zastrzeżeń do stawianych diagnoz, jak też udzielanych wskazówek w odniesieniu do specjalistów pracujących w obrębie modelu multidyscyplinarnego. Budowany obraz Innego jest obrazem całościowym, zaś hipotezy weryfikowane $\mathrm{w}$ aspekcie praktycznym w niewielkim tylko stopniu zakładają popełnianie błędu, co bezpośrednio przekłada się na konstruowanie adekwatnych programów wspierających.

Zespół transdycylinarny zakłada, iż wszyscy specjaliści danego zespołu będą dokonywali wspólnej diagnozy, włączając w to rodziców, którzy są traktowani jako pełnoprawni i aktywni członkowie, jak też będą wspólnie opracowywali jeden wspólny plan pracy z Innym, uwzględniając potrzeby rodziny. Analizując proces diagnozy, w którym biorą udział wszyscy członkowie, wymienia się działania skoncentrowane na wyborze jednej osoby, która dokonuje tzw. inwentarza środowiska, w którym Inny przebywa, a także określa konieczne aktywności i umiejętności, których opanowanie

${ }^{16}$ M. Piszczek, Różne modele funkcjonowania zespołu specjalistów odpowiedzialnych za diagnozę i edukację dzieci głębiej upośledzonych umystowo, "Rewalidacja” 2002, nr 1(7), s. $90-112$. 
pozwoli Innemu efektywnie funkcjonować w określonym środowisku. Każdy ze specjalistów ma wgląd do inwentarza i nanosi tam swoje sugestie, których celem jest optymalizacja funkcjonowania Innego. W dalszym etapie zespół dokonuje diagnozy umiejętności funkcjonalnych poprzez wykorzystanie określonych metod i technik diagnostycznych. Kolejnym krokiem jest określenie rodzaju i stopnia wsparcia oraz sformułowanie celów określonych działan realizowanych w oparciu o wspólne założenia.

Wszyscy realizatorzy indywidualnego programu biorą odpowiedzialność za jego przebieg. Przy czym warto podkreślić, iż w modelu tym jest wyznaczana osoba, która będzie realizowała plan wraz z rodzicami. Zespoły odbywają regularne spotkania wszystkich jego członków, podczas których jest możliwa wspólna wymiana doświadczeń (w zakresie informacji, wiedzy i umiejętności). Każdy ze specjalistów, jeśli istnieje taka potrzeba, może przekraczać granice w obrębie działań innych specjalistów, co sprzyja poszerzaniu indywidualnych kompetencji, ale też usprawnia pracę całego zespołu. Model transdyscyplinarny funkcjonuje od wielu lat w placówkach w zachodnich krajach europejskich. Przy czym w ostatnim czasie zauważa się stopniowe wdrażanie go do placówek także w naszym kraju.

\section{Kompetencje zespołu terapeutycznego w ujęciu teorii rozwoju kompetencji zawodowych Stefana Kwiatkowskiego}

Stefan Kwiatkowski zaproponował teorię rozwoju zawodowego, która uwzględnia dynamikę zmian w kompetencjach zawodowych. Zgodnie z jego teorią rozwój kompetencji może być poddawany analizie w kontekście zmian w zakresie wiedzy, umiejętności i kompetencji społecznych. Można je rozpatrywać w trzech ujęciach: 1) rozwoju - przyrostu wiedzy, umiejętności i kompetencji, 2) stagnacji - braku przyrostu wiedzy, umiejętności i kompetencji społecznych, 3) regresu - ubytku wiedzy, umiejętności i kompetencji 
społecznych ${ }^{17}$. W każdym z tych opisów występuje przyrost, brak przyrostu, ubytek w odniesieniu do wiedzy, umiejętności i kompetencji społecznych.

Rozwój w zakresie kompetencji zawodowych może mieć charakter liniowy lub skokowy i rozpatrywany jest w sytuacji systematycznego przyrostu wiedzy, umiejętności i kompetencji społecznych ${ }^{18}$. Rozwój uwarunkowany jest czynnikami endo- i egzogennymi zarówno na poziomie indywidualnym (aspiracje i możliwości członków zespołu), jak i grupowym. W zasadzie rozwój kompetencji zespołów terapeutycznych jest wypadkową uwarunkowań wewnętrznych zależnych od poszczególnych członków zespołu oraz warunków zewnętrznych uzależnionych od placówki.

W modelu multidyscyplinarnym i interdyscyplinarnym rozwój kompetencji zespołu może być utożsamiany z niezależnym indywidualnym rozwojem każdego specjalisty, a to oznacza tylko tyle, że jest niezależnym doskonaleniem zawodowym w obrębie danej specjalności. Specjalista - członek zespołu doskonali się, rozszerzając wiedzę, doskonaląc umiejętności i kompetencje społeczne (miękkie). Każda kompetencja każdego specjalisty może być w procesie rozwoju, stagnacji albo regresu. Mogą tu nastąpić różne kompilacje. Istotą jest to, że w sytuacji, gdy rozwój poszczególnych członków zespołu jest niezależny, planowy przez nich, a nie przez zespoły czy koordynatorów zespołu, jest jednak zgodny z potrzebami zespołu. W takiej sytuacji można uznać, że w jakiś sposób zespół się doskonali, chociaż jest to doskonalenie nieplanowane, które pojawia się jako coś dodatkowego.

W przypadku zespołu transdycyplinarnego rozwojowi podlegają kompetencje zespołu, co oznacza, że planowany rozwój kompetencji wymaga diagnozy potrzeb wynikających $\mathrm{z}$ podstawowych zadań zespołu, a także z możliwości członków zespołu z uwzględnieniem aktualnych i potencjalnych zadań zespołowych i progra-

17 S. Kwiatkowski, Rozwój kompetencji zawodowych w procesie pracy, „Szkoła. Zawód. Praca" 2016, nr 12, s. 14.

18 Ibidem, s. 16. 
mowania na tej podstawie działań edukacyjnych - ma on wtedy charakter liniowy. Oczywiście włączając wszystkich członków zespołu, przy czym niekoniecznie musi to być zgodne z ich profesją. Warto raz jeszcze podkreślić, iż w modelu transdycyplinarnym przekraczane są granice między specjalnościami.

Ważne jest też to, żeby zdiagnozować jakie kompetencje w zespole są potrzebne i oczywiście można również pamiętać o tym, że te kompetencje zespołu mogą być w stanie rozwoju, stagnacji albo regresu. Wówczas trzeba zdiagnozować, $z$ jakiego powodu one znajdują się $\mathrm{w}$ danym stanie $\mathrm{z}$ uwzględnieniem obszaru wiedzy, umiejętności czy kompetencji społecznych. Istotne znaczenie w procesie rozwoju zespołów terapeutycznych mają także czynniki zewnętrzne, którymi mogą być możliwości placówki, w której funkcjonuje zespół - ma on wtedy charakter skokowy.

Biorąc pod uwagę fakt, że rozwój kompetencji zespołu terapeutycznego uzależniony jest także od czynników zewnętrznych takich jak placówka, warto zwrócić uwagę na istotne jej cechy, wśród których można wyróżnić następujące zmienne: 1) wielkość, 2) stosowane metody pracy, 3) sytuację ekonomiczną, 4) świadomość kadry zarządzającej. W zależności od zaistniałych uwarunkowania poszczególnych czynników, zachodzą procesy rozwoju stagnacji lub regresu w zakresie funkcjonowania zespołów terapeutycznych w procesie wspierania Innego.

Całkowicie normalną sytuacją w pracy zespołów terapeutycznych jest to, że obok etapu/czasu rozwoju pojawiają się także etapy/czas stagnacji i regresu. Istotne rolę w tych etapach odgrywa czas. Długotrwała stagnacja, a tym bardziej regres w zakresie pracy zespołu terapeutycznego nie służy wspieraniu Innego. Analizując rozwój kompetencji zespołu terapeutycznego uzależniony od wewnętrznych cech poszczególnych członków zespołu, interesująca jest analiza czynników powodujących stagnację lub regres poszczególnych kompetencji w zakresie wiedzy, umiejętności i kompetencji społecznych. Biorąc pod uwagę wiedzę, można sądzić, że podczas długotrwałej realizacji zadań typowych i powtarzalnych w pracy zespołu rozpadowi ulega wcześniej zdobyta przez poszczególnych 
członków zespołu wiedza. Do podobnych zmian może dochodzić w zakresie umiejętności, bowiem ich rozwój wymaga nowych zadań o podwyższonym stopniu trudności i złożoności, jeśli ten warunek nie jest spełniany w pracy zespołu terapeutycznego, możemy liczyć się z wystąpieniem ryzyka stagnacji, a nawet regresu. Analizując kwestię kompetencji społecznych, warto podkreślić, że jest to jeden ze stałych komponentów, bowiem w dużej mierze uzależniony jest od indywidualnych cech poszczególnych członków zespołu terapeutycznego.

Na opisane powyżej uwarunkowania zewnętrzne mają wpływ indywidualne aspiracje poszczególnych członków zespołu terapeutycznego, bowiem niski poziom aspiracji, nawet przy najbardziej sprzyjającym układzie wyżej wymienionych zmiennych, utrudnia lub spowalnia rozwój całego zespołu we wspieraniu Innego.

\section{Zakończenie}

W rozwoju kompetencji zespołów terapeutycznych kluczowe wydaje się być określenie wspólnego celu przez przedstawicieli (specjalistów) poszczególnych dyscyplin. Dzięki temu praca w zespołach terapeutycznych składających się z przedstawicieli różnych specjalizacji daje możliwość uwzględnienia wielu punktów widzenia osiąganych sukcesów, jak też ujawnianych trudności, co pozwala na wypracowanie wspólnych standardów pracy, a co za tym idzie, pełnego zakresu wsparcia Innego. Zdolności organizacyjne i współpraca oraz profesjonalizm zespołów terapeutycznych nie może być uważany za zindywidualizowany zestaw kompetencji, ale powinien funkcjonować jako element organizacyjny wpisany w funkcjonowanie danej instytucji. Zdolność i gotowość do doskonalenia swoich umiejętności, a także chęci do dzielenia się nimi z innymi to jeden z najważniejszych rozwoju zespołu.

W wielu instytucjach daje się zauważyć to, iż poszczególni specjaliści są wciąż „zamknięci w szufladzie” swojego obszaru specjali- 
zacji. Świadczy o tym brak podejmowania inicjatyw na rzecz tworzenia wspólnych transdysplinarnych projektów wykraczających poza indywidualne obszary zainteresowań.

W sytuacji konieczności działania zespołowego może pojawić się niechęć poszczególnych członków do wspólnego działania. Wśród przyczyn można wskazać tu: dostrzeganie konieczności zmian dotychczasowego i rutynowego postępowania, co wymaga od poszczególnych członków zmian w zakresie schematycznego działania i zaangażowania w tworzenie nowych standardów pracy. Co więcej, towarzyszące niepokoje mogą ujawniać się postrzeganiem przez specjalistów własnej niekompetencji w danym zagadnieniu oraz płynące $\mathrm{z}$ indywidualnych doświadczeń przekonanie, że praca zespołowa niczemu nie służy, za wyjątkiem stwarzania pozorów demokracji i równości poszczególnych członków zespołu. Zespół funkcjonujący w ramach wspólnych działań i wypracowane rezultaty $\mathrm{w}$ ocenie poszczególnych członków nie muszą koniecznie służyć działaniom podjętym na rzecz wspierania Innego. Ponadto niepokojące jest pojawienie się nieformalnych liderów, którzy uzyskują wysoki autorytet niektórych specjalistów. To determinuje zmianę dotychczasowej struktury danego zespołu, powodując trudności w zakresie sprawnego nim kierowania, szczególnie kiedy członkowie są oponentami w stosunku do dotychczasowego lidera. Biorąc pod uwagę uwarunkowania organizacyjno-prawe w zakresie działania zespołów, istnieje obawa, że niektórzy jego członkowie mogą swoją pracę na rzecz zespołu traktować jako przymus i konieczność. Utrzymujący się przez dłuższy czas, taki stan może prowadzić do syndromu wypalenia zawodowego poszczególnych członków zespołu. Wpływa to nie tylko na efektywność wspierania Innego, ale także na brak zainteresowania prezentacją rezultatów pracy zespołowej koleżanek i kolegów. Jednak nawet ci specjaliści, którzy są zaangażowani we współpracę zespołu, nie dzielą się $\mathrm{z}$ innymi swoim odczuciami, bowiem obawiają się krytyki ze strony współpracowników, a także nadmiernego obarczania ich dodatkową pracą, której celem byłaby poprawa jakości zaniedbanego obszaru działań innego specjalisty. 


\section{Bibliografia}

Encyklopedia, PWN, Warszawa 1996.

Hulek A., Podstawy, stan obecny i przyszłość edukacji osób niepetnosprawnych, [w:] Edukacja osób niepetnosprawnych, red. A. Hulek, „UN-O”, Warszawa 1993.

Kapuściński R., Ten Inny, Wydawnictwo Znak, Kraków 2006.

Kwiatkowska H., Pedeutologia, Wydawnictwa Akademickie i Profesjonalne, Warszawa 2008.

Kwiatkowski S., Rozwój kompetencji zawodowych w procesie pracy, „Szkoła. Zawód. Praca" 2016, nr 12.

Piszczek M., Różne modele funkcjonowania zespołu specjalistów odpowiedzialnych za diagnozę i edukację dzieci głębiej upośledzonych umystowo, „Rewalidacja” 2002, nr 1(7).

Rzedzicka K.D., Nauczycielska relacja z Innym w pedagogice specjalnej, [w:]: Pedagogika specjalna szansą na realizacje potrzeb osób z odchyleniami od normy, red. W. Dykcik, Cz. Kosakowski, J. Kuczyńska-Kwapisz, Wydawnictwo Naukowe PTP, Olsztyn - Poznań - Warszawa 2002.

Szempruch J., Kompetencja komunikacyjna nauczycieli w działaniach edukacyjnych, [w:] Edukacja jutra. Aspekty wychowania i kształcenia we wspótczesnej szkole, red. A. Kamińska, P. Oleśniewicz, Oficyna Wydawnicza Humanitas, Sosnowiec 2016.

Wilczek-Rużyczka E., Komunikowanie się z chorym psychicznie, Wydawnictwo Czelej, Lublin 2007.

Rozporządzenie Ministra Edukacji Narodowej w sprawie organizowania wczesnego wspomagania (Dz. U. poz. 1257 z dnia 11.10.2013 r. i Dz. U. poz. 133 z dnia 3.02.2009 r.).

Rozporządzenie Ministra Edukacji Narodowej w sprawie warunków organizowania kształcenia, wychowania i opieki dla dzieci i młodzieży niepełnosprawnych, niedostosowanych społecznie i zagrożonych niedostosowaniem społecznym (Dz. U. poz. 1113 z dnia 24.07.2015 r.).

Rozporządzenie Ministra Gospodarki, Pracy i Polityki Społecznej z dnia 25.03.2004 roku w sprawie warsztatów terapii zajęciowej (Dz. U. Nr 63, poz. 586 i 587).

Rozporządzenie Ministra Zdrowia z dnia 21.12.2010 r. w sprawie rodzajów i zakresu dokumentacji medycznej oraz sposobu jej przetwarzania (Dz. U. z dnia 29.12.2010 r. Nr 252, poz. 1697).

Rozporządzenie Ministra Zdrowia z dnia 27.12.2007 r. w sprawie sposobu i kryteriów ustalania dopuszczalnego czasu oczekiwania na wybrane świadczenia opieki zdrowotnej (Dz. U. z 31.12.2007 r. Nr 250, poz. 1884).

Rozporządzenie Ministra Zdrowia z dnia 29.08.2009 r. w sprawie świadczeń gwarantowanych z zakresu podstawowej opieki zdrowotnej (Dz. U. z 31.08.2009 r. Nr 139, poz. 1139).

Sowa, J., Znaczenie procesu instytucji wspomagajacych proces rehabilitacji, „Szkoła Specjalna" 2003, nr 3(220), tom LXIV. 
Ustawa z dnia 15.04.2011 r. o działalności leczniczej (Dz. U. z 15.02.2013 r., poz. 217 j.t. z późn. zm.).

Ustawa z dnia 27.08.2004 r. o świadczeniach opieki zdrowotnej finansowanych ze środków publicznych (Dz. U. z 11.09.2008 r. Nr 164, poz. 1027 j.t. z późn. zm.). 